\title{
Quando a guerra faz da verdade um butim
}

Fabio Henrique Gonçalves ${ }^{*}$

Filme: KATYN. Polônia, 2007. Direção: Andrezj Wajda.

Mas afinal, o que é a verdade histórica? De fato ela existe? Talvez como algo a ser descoberto e revelado, bastando para isso atravessar com método e persistência a espessa névoa das aparências? Como defini-la? A partir da consideração de que deve haver por fim um dado inescapável, um fato acima de quaisquer discussões? Ou pelo contrário, faz-se necessário colocar o conceito de verdade no rol não das certezas, mas das possibilidades? Neste caso, em se tratando da História enquanto narrativa, a verdade assumiria somente a face da "possibilidade de um acontecido", apenas uma interpretação entre tantas outras a serem construídas?

Sob esta última perspectiva, a legitimidade de uma verdade histórica deslocar-se-ia do acontecimento que Ihe serviria de lastro para o resultado de uma produção - ou de uma operação historiográfica, como diria Michel de Certeau. Percorrendo este caminho, coloca-se então o desafio de perceber a verdade histórica para além da naturalidade com a qual ainda vez por outra é encarada, e por isso mesmo não discutida. A inquietação é saber que batalhas são travadas em seu nome. Lutas que giram não propriamente em torno de algo a ser apreendido, um objeto a ser conquistado, mas antes pelo direito ao próprio ato criador. É o caso de, numa postura mínima de prudência, desconfiar de qualquer transposição para a História da assertiva de que "a verdade vos libertará". Se a verdade histórica é fabricada, ela também pode ser manipulada e imposta, constituindo-se numa prisão tanto mais eficiente quanto seja sutil e naturalizada, tanto mais perene quanto se puder matar em seu nome.

Katyn convida ao questionamento da verdade histórica ao tocar numa ferida aberta há quase setenta anos: o assassinato de aproximadamente 12 mil oficiais poloneses durante a Segunda Guerra Mundial. Levados à floresta que dá nome ao filme, eles foram executados e sepultados numa vala

\footnotetext{
* Mestrando em História Social pela Universidade de Brasília (UnB). Bolsista do Fundo de Amparo à Pesquisa e ao Desenvolvimento Científico e Tecnológico do Maranhão (FAPEMA).
} 
comum. Dentro daquele imenso conflito, teve lugar outra disputa. Desta vez, pela imputação da responsabilidade sobre o massacre, em que se revezaram os papéis de acusados e acusadores. Quando a verdade histórica se mostrou antes de tudo como uma tela em branco, sobre a qual foram desenhadas, em momentos diferentes, versões distintas para o mesmo fato, preenchidas com as cores de ideologias dispostas a tudo na legitimação de seus discursos.

O filme tem início em setembro de 1939, quando as tropas alemãs e soviéticas, vindas de direções opostas, invadem a Polônia. Em decorrência do Pacto Hitler-Stalin, assinado em agosto daquele ano, os poloneses viram seu território ser dividido em zonas de ocupação da Alemanha e da URSS. Acompanhamos então o oficial polonês Andrzej. Junto com seus companheiros de farda, ele é feito prisioneiro pelos soviéticos e enviado para um campo em Kozielsk. "Eles nos tomam como prisioneiros de guerra, embora não houvesse guerra", escreve um ainda atônito Andrzej no diário em que começa a registrar todos aqueles acontecimentos. Enquanto isso, o pai, professor universitário na cidade de Cracóvia, tomada pelos alemães, é enviado a um campo de trabalho. Recurso adotado pelo diretor Andrezj Wajda para registrar a dupla tragédia de um país que naquele momento se mostrava geograficamente desafortunado e com a própria identidade posta em suspensão. Wajda que teve o pai morto pela NKVD, a polícia secreta da URSS. Uma tragédia pessoal que, de forma compreensível e para a tristeza dos puristas da tal imparcialidade, deve ter influenciado na condução do filme, ou na própria escolha do tema. O diretor já ocuparia assim um lugar de fala bem particular.

Dois cortes são decisivos no desenrolar do filme. Primeiro Cracóvia, em 1943. Os anos passam e o desenrolar da guerra põe antigos aliados em lados opostos. A URSS já tinha a Alemanha nazista como oficialmente inimiga. Naquele ano, os alemães descobrem os cadáveres de milhares de oficiais poloneses na floresta de Katyn, apontando em seguida para o culpado: o exército soviético. Numa cena vemos dois oficiais alemães que tentam a todo custo convencer a viúva de um general polonês a gravar um depoimento condenando os assassinatos e pedindo punição aos soviéticos. Diante da hesitação daquela senhora, mesmo ameaçada com o envio a Auschwitz, os oficiais projetam imagens dos corpos desencavados, tendo ao fundo uma narração que enfatiza que os poloneses foram assassinados da típica maneira 
bolchevique: um tiro na nuca. O massacre, apontado como tendo acontecido na primavera de 1940 (as datas têm aqui muita importância), alerta contra a "praga assassina bolchevique" e ressalta o papel dos alemães na proteção do continente.

Em seguida, o cenário ainda é Cracóvia. Porém, estamos agora em 1945. A Alemanha de Hitler foi vencida. Os destinos da Polônia giram na órbita soviética. $\mathrm{E}$ os acontecimentos presentes não têm a capacidade de moldar apenas o futuro. Quebrando o que só inicialmente poderia ser um absurdo, o passado também será alterado. Em praça pública os soviéticos exibem um pequeno documentário. Novamente as imagens do massacre de Katyn na tela. As mesmas pilhas de corpos amontoados, petrificados. Mais uma vez um narrador que enfatiza o horror das cenas e a crueldade dos assassinos. Entretanto, algo mudou. E que pode ser sintetizado pelo texto que é narrado ao fundo: "Um tiro na nuca, estilo favorito dos assassinos da Gestapo". Não, nada de 1940. Segundo os peritos soviéticos, a autópsia não deixava margens para dúvidas. Pelo estado dos cérebros e das roupas, aqueles poloneses não foram mortos antes do outono de 1941. Mortos pelos alemães.

Assim, uma verdade "mais verdadeira" entra em cena. Torna-se a única, ainda que muitos poloneses se mostrem desconfiados, quando não convictos de que se trata de uma grande farsa. Mas para os soviéticos isto pode ser remediado, a exemplo da referida divulgação das imagens do "terrível crime perpetrado pelos alemães”. E se algumas pessoas insistirem que existe outra verdade, se não há como colocar em suas cabeças que estão iludidas por um erro, que ao menos silenciem de boa vontade, caso não queiram que isto seja feito de modo mais incisivo. Como o jovem Tadzio, que vê seu ingresso na escola de artes ameaçado por ter incluído em seu currículo que o pai morrera em Katyn, em 1940. Preço mais alto pagaria a bela Agnieszka, que insiste na encomenda de uma lápide para o irmão, contendo, na inscrição, o mesmo fatídico ano:

Oficial soviético: Você sabe que foram os alemães. E colocou uma placa no cemitério com uma data falsa da morte de seu irmão, de 1940. Você quer difamar os camaradas soviéticos?

Agnieszka: Estou interessada na verdade.

Oficial soviético: $A$ verdade é dada. 
Personagens que, em gestos aparentemente mínimos, tentam vencer o que consideram a usurpação do último resquício de dignidade. Inconformados em que, após o desaparecimento de parentes e amigos, os criminosos triunfem mais uma vez, agora por meio da construção de uma memória. Insurgem-se contra a determinação oficial do que deve ser lembrado e, mais importante, de como essa lembrança dessa estar configurada.

Debate sobre a construção da memória que faz lembrar o artigo de Alessandro Portelli sobre outro massacre (o de Civitella), quando o historiador italiano tomou de empréstimo a Giovanni Contini a expressão "memória dividida" para se referir às lembranças construídas em torno daquele fato. Naquela ocasião, também no contexto da $2^{a}$ guerra mundial, aproximadamente 115 civis foram mortos por oficiais nazistas na cidade italiana de Civitella Val di Chiana, possivelmente em retaliação ao assassinato de três soldados alemães pela Resistência local. Massacre que deu margem a duas interpretações: uma, "oficial", que vê os partisans como heróis, por não se renderem às forças de Hitler; outra, que os considera culpados pela morte de inocentes, causada por seu enfrentamento irresponsável às tropas alemãs. Onde está a verdade? Talvez muito mais significativo que persistir numa resposta "correta", seja frisar, como faz Portelli, que aquilo denominado memória coletiva é formado pela mediação de ideologias, linguagens, senso comum e instituições. Memória que "não é um núcleo compacto e impenetrável para o pensamento e a linguagem, mas um processo moldado ('elaborado') no tempo histórico"1.

Somados às tragédias pessoais de suas personagens, Katyn busca apresentar os dilemas da própria Polônia pós-guerra, as cicatrizes em sua identidade, o orgulho ferido, a autonomia ainda por (re) conquistar, o direito ao próprio passado. Um país em intenso conflito, que não sabe bem ao certo aonde ir, o que fazer neste mundo que surge após tantos anos de combates.

Dilemas que, no filme, tem o oficial polonês Jerzy como encarnação. Ele que escapou de ser uma vítima na floresta de Katyn para, anos depois, testemunhar a favor da versão montada pelos soviéticos, imputando a culpa daquele massacre aos alemães. O antigo tenente, que virou major na Polônia dominada pelos comunistas, carrega uma consciência atormentada pelo fato

\footnotetext{
1 Artigo consultado no endereço eletrônico http://www.cholonautas.edu.pe/memoria/portelli1.pdf em $10 / 05 / 2010$
} 
de ter sobrevivido num mundo que vê repleto de mentiras. Ele tenta em vão justificar a si mesmo tudo aquilo, num tom de pragmatismo desesperado: "Não faz diferença se são soviéticos ou alemães. Ninguém ressuscitará os mortos. Temos que sobreviver, perdoar. Temos que viver".

Já se disse que a História é contada pelos vencedores. Em Katyn, muito mais que um mero despojo da luta, as verdades criadas, repetidas e aprendidas acabarão por se transformar na própria luta, quando acontecimento e representação poderão por fim ser uma coisa só. 